\title{
Personal status and exceptions of the national law enforcement regarding it
}

\author{
Abasat Pour Mohammad ${ }^{1}$, Behnam Ramazani ${ }^{2}$ and Mahdi Mohammad Zadeh ${ }^{3}$ \\ 1 Corresponding Author: Assistant Professor, Department of Law, Maragheh Branch, Islamic Azad University, Maragheh, Iran. E-mail: \\ dr_a_p20@yahoo.com \\ 2 PhD Student, Department of Law, Maragheh Branch, Islamic Azad University, Maragheh, Iran. \\ 3 PhD Student, Department of Law, Maragheh Branch, Islamic Azad University, Maragheh, Iran.
}

\begin{abstract}
Personal status arises from Roman law and is consisted of two main elements being status and qualification .it is the result of a division that exists in the Roman Law System. Nowadays, it is considered as a core element of civil rights since the latter is divided into two divisions of personal status and objective status. By personal status it is referred to characteristics that determine an individual's personal and legal status and identity as well as the assignments of the person in society. The former status belongs to the self and is not separated from his/her social status. In addition, it is not exchangeable and cannot be turned into cash. For example, marriage and divorce or in other words anything that amplifies the relation between the person and his/her family are considered as personal statuses and on the other hand, anything related to financial relations is considered as objective status. Laws governing personal status are in general the same laws of the government; however this law has its exceptions including public discipline, minorities, genealogy, qualification and individuals with no citizenship which are discussed in the present article.
\end{abstract}

Keywords: personal status, qualification, status, citizenship, residence, alien.

\section{INTRODUCTION}

Personal status is a new phrase which has current applications in civil codes and international laws. This phrase has no history in juridical texts. In other words, the former phrase belongs to contemporary laws and is derived from French Rights. Prior to addition of the former phrase, personal status in France was considered as a function of residence law. In addition, some scholars of French Law were concerned about further manipulation and alteration of laws and therefore instead of current residence, they considered the original residence as the criteria for action. The evolution resulted by French Civil Code found its way to other countries and as a result, the principle of enforcement of national law regarding personal status was accepted in major parts of Europe and some parts of Latin America. However, in U.K and in general, in EnglishAmerican rights, the principle of enforcement of residence law has remained still. The principle of enforcement of national law regarding personal status was approved by the international law institute during meetings held in 1900s. In addition, it was also accepted in multidimensional political treaties of 1902 and 1905 of Hague (NASIRI, 2016).

From the perspective of legal analysis, the phrase of personal status has been implemented in two contexts, with one of them being a general definition including status and qualification as it has been con- 
sidered by the article 6 of the civil rights; and the other being a specific that is only used for condition as it has been used by the article 7 of the civil rights (IMAMI, 2002). However, it is obvious and clear that one of the boldest characteristics of personal status is that it is not exchangeable and cannot be interchanged with money and also has no relation with the person's occupational or social status (SAFAEI ET AL., 2016).

\section{DEFINING PERSONAL STATUS}

In legal terms, Personal status is defined as characteristics and descriptions which determine an individual's personal and legal status and identity as well as the assignments of the person in society. In other words, by personal status it is referred to the descriptions that are only related to the self and are not related to occupational and social statuses of the person. Therefore, the former is not interchangeable with money and is not exchangeable at all. On the other hand, the term of personal status has been occasionally used in contrast to objective status which is related to financial issues.

\section{EXAMPLES OF PERSONAL STATUS}

Examples of personal status in Iran include the events related to articles such as articles 6 and 7 of the civil rights and principles 12 and 13 of the constitution and also the single article of permission of consideration of personal status of non-Shia Iranians. The former events include marriage, divorce, inheritance, wills, qualifications, adoption, guardianship, discrimination, dowry, paternity, ancestry, mandate, twig and stone treatment (NOWROOZI, 2017). It is also worth mentioning that among the aforementioned affairs, two cases of discrimination and adoption do not exist in Shia Jurisprudence, however the rest of the affairs have been deeply investigated under different contexts of jurisprudence.

Status: the sum of legal rights of an individual in a society. On the other hand, civil status includes the status of rights of persons in the context of personal rights relations and especially, family relations including marriage, divorce, childhood and adolescence, birth and death. Persons' status defines their rights and assignments.

Qualification: in terms of vocabulary, it is defined as capability or competence of human. In legal terms, it refers to person's legal qualification for having right and enforcement of justice. On this basis, qualification is in two types: first, qualification for merit and second, qualification for enforcement (JAFARI LANGROODI, 2014).

Qualification for merit includes the competence for having a right. For example, a natural person has the right of marriage but a legal entity doesn't. On the other hand, it cannot be said that whoever has merit qualification is able to enforce it because, there is also another required type of qualification which is called the enforcement qualification (JAFARI LANGROODI, 2014). Not every disqualified person is necessarily called incapacitated. For example, a foreign citizen may not be qualified for having voting right, and may not be incapacitated as well. However, in most cases people with disqualification are incapacitated. On the other hand, for those who have reached puberty and their growth is evident, the law states that they are qualified for enforcement. Article 121 of the civil rights states that boys' and girls' puberty ages are respectively, 15 and 
9 years. In addition, appendix 2 of the article 1210 of the civil rights states that qualification for merit has no legal dependence on qualification for enforcement. In other words, a child can own any type of property, but he/she will not be able to enforce his/her ownership rights until the age of puberty. What this paper elaborates on regarding foreign citizens is only the enforcement qualification.

\section{THE RELATIONSHIP BETWEEN STATUS AND QUALIFICATION}

In spite of differences that exist between these two expressions, there also exists a close relationship between them. In this regard it can be claimed that a person's qualification is the result of his/her status. Because person's status determines his/her rights and assignments, and legal qualifications of the person will also be functions of his/her status.

\section{THE LAW GOVERNING PERSONAL STATUS}

Taking into account that private international laws tend to geographically categorize persons, it is clear why these laws emphasize on residence and citizenship. In fact they pose the question whether personal status of foreigners who are citizens of another country is ruled by norms of the laws of their origin country or by rules of their residence? However, the former question is brought up only when the qualification law regarding the conflicted issue is made clear. Regarding the question about the law governing the personal status of foreigners, most countries have followed the following two opinions:

1 - Residence law

Estação Científica (UNIFAP)

ISSN 2179-1902
2 - National law

\section{RESIDENCE LAW}

Residence is a legal relation accompanied with certain political characteristics that are established between persons and a specific domain of the government (NASIRI, 2016). The precondition for inhabitancy is not necessarily being a citizen of the target country. Therefore, residence is the materialistic division of persons against law of persons' spiritual division. Article 1002 of the civil code states: residence is where the individual lives and most of his/her important affairs take place. If the place of residence of a person is other than the place in which his/her important affairs take place, then the place of affairs is considered as the residence. Residence of legal entities is considered the same as their operations center.

There are three main principles ruling over residence: first of all, every person should have a residence, second, no individual is allowed to have more than one residence and third, residence is not permanent. There exist differences between various countries regarding the principle of unity of residence.

Most countries including France, England, Switzerland and etc. have accepted the principle of unity. In addition, the civil code has accepted it too. However, some countries including Germany and Afghanistan haven't still accepted it. Therefore it can be seen that different countries have adopted different approaches towards governance of national law or residence law over persons' personal status. The AngloSaxon law system has selected the residence law as the law governing persons' personal status. Proponents of this ideology 
are mostly oriented towards social and political synchronization. They want a unit and universal law ruling over the entire people of a country so that in addition to their primary intentions, the principle of equality of rights is enforced, followers of different religions are brought closer to each other and provided with increased social synchronization (NASIRI, 2016).

Savini is the founder of the residence theory. He doesn't consider governments' benefits and states: citizenship is a political, legal and spiritual relation between the person and government. When a person goes from one country to another and selects the destination as his/her residence and base of important affairs, the aforementioned relations become stronger with time. In fact while the person's relations with his/her original government fade, the relations with the destination government strengthen. In terms of determining law governing foreign personal status one cannot ignore the facts. Therefore countries such as France and Switzerland have recently been oriented towards this trend (NASIRI, 2016).

\section{NATIONAL LAW}

The original government law was for the first time proposed by the authors of French Civil Code regarding solvation of conflicts between laws. Many of the countries around the globe, especially European countries accepted this principle. However, this principle has exceptions too. One of these exceptions is public discipline or order. The advantages of national law include: firstly it is consistent with objectives of personal laws which are established to support people and require persistence and conti- nuity and doesn't change with movement of people. Resultantly family pillars are remained still which is the main objective of personal laws. Secondly, it is consistent with the popular principle of international laws (international comity) which insists on (international comity) which insists on adherence to justice in international scenes and respecting others (IMAMI, 2002).

As a final point, it can be said that Iranian civil code has followed the original government principle and it has been clearly stated in article 7 of the civil code. In this regard, some scholars have stated: if a country considers the personal status of a foreigner as under the rule of residence country and believes that enforcement of foreign law is only done upon mutual behavior, this would be considered as a sign of lagging.

Different countries usually make use of the either of elements of residence or citizenship for determining the law governing personal status of persons. Regarding the advantage and efficiency of the either of the aforementioned elements over the other; it should be said that this is a relative issue and is different for every country. However, by making use of the national law, family status and qualification of persons are better supplied. However, selecting one of these two laws is more dependent on convenience reasons rather than legal reasons.

\section{LAW GOVERNING THE PERSONAL STATUS OF IRANIANS WITH FOREIGN RESIDENCE}

Iran is one of the countries in which persons' personal status depend on their government laws. Article 6 of the civil code has emphasized on application of the national 
law for personal status of Iranians with foreign residence. By this means, every Iranian citizen's personal status whether with foreign residence or domestic residence are governed by national laws. Examples of personal status may include marriage, divorce, qualification and etc. in addition it must be pointed out that personal status doesn't only include counts such as marriage and divorce and it also includes other examples such as legal guardianship and etc.

\section{PERSONAL STATUS OF NON-SHIA IRANIANS}

Regarding non-Shia Iranians, as we have in the related article called the permission for adherence to personal status of nonShia Iranians, minorities with non-Shia Islamic religions and or other booked religions are governed by their own religions and habits. This principle is also present in private international laws too. In this regard, non-Shia Iranians with foreign residence are included in this law. However, this law is only enforced for those whose religion has been officially recognized. With respect to principle 4 of the constitution of Islamic Republic of Iran and the principles of Islamic Private international laws, Muslim Foreigners who live in Iran are included in their own religious law even in case of existence of treaties (regarding personal status). Therefore it can be stated that Sunni Muslims and followers of other booked religions adhere to their own religious laws regarding the following affairs:

1 - Affairs related to marriage, divorce, inheritance and wills

2 - Affairs related to adoption
10 LAWS GOVERNING THE PERSONAL STATUS OF FOREIGNERS IN IRAN

Article 7 of civil code of Iran states that foreigners citizens of Iran should follow their government's laws regarding affairs related to their personal status and qualification and affairs including inheritance. However, in this regard all Iranian courts should always first study the treaties between Iran the governments of the foreigners. However, since there are sometimes certain descriptive inconsistencies between countries regarding determination of examples of personal status, governments are always trying to establish treaties in order to avoid the inconsistencies of descriptions. As an example it can be referred to the residence treaty between Iran and Switzerland. In article 8 of this treaty it has been stated that: in issues regarding personal, family and inheritance rights, every citizen on the land of the other end of the treaty is ruled by the laws of his/her original country and the other end of the treaty cannot deviate from enforcements of mentioned rules. Both sides and ends of this treaty have agreed that the following are included as personal status: Marriage, the couple's property, divorce, discrimination, dowry, paternity, birth, adoption, legal capacity, maturity, guardianship and trusteeship, right of inheritance, purification and division of estate or property and in general, every issue related to family rights and the entire affairs related to personal status. Therefore, by setting the margins and extensions of personal status and agreement of the aforementioned governments on the former, there will be no more conflicts regarding description of personal status. 
11 DIFFERENT CASES OF ENFORCE-MENT OF LAWS GOVERNING PERSO-NAL STATUS

There are cases in which the principles of law conflicts are not applicable. In other words, enforcement of the law of the original government may face problems which occasionally include:

1 - Lack of unity among foreign laws

2 - Lack of existence of laws regarding personal status

3 - Having several citizenships (more than one)

Lack of unity between foreign laws

There are some countries which have no united rules regarding personal status. For example it can be referred to federal countries or some extensive countries such as Iran. In these cases, citizens of a single government may be subjected to different rules. In terms of conflicts between rules, if national laws become dominant over personal status, then every citizen will be subjected to his/her own specific laws. For example for personal status of non-Shia Iranians living in foreign countries such as France which have accepted the national law regulation, the same laws of the residence country will be in effect. The same is done with foreign citizens living in Iran.

Lack of existence of laws regarding personal status

The original country of a person may lack laws regarding personal status. What should be done in this case?

It may be said that in these cases the residence rule is applied. This solution is acceptable in countries such as France in which residence has an alternative role. But in case of Iran, it is not acceptable. In Iran, the law of Iran is meant to be enforced as the law of court. Enforcement of law in the- se cases depends on the article 5 of civil code. This law considers the entire residents of Iran as subject $s$ to Iranian laws except for legal exceptions.

Having multiple citizenships

The principle implies that whoever has a citizenship is able to change it. Citizenship is based on soil system (birth place) and or blood system (residence of parents).

Cases of occurrence of multiple citizenships

Birth related citizenship multiplicity means that a person will have two citizenships at the time of birth. It means that he/she is born in a country which accepts his/her citizenship while the parents are citizens of another country. For example, according to article 976 of the Iranian civil code, those whose fathers are Iranian, are considered as Iranians no matter having been born in Iran on other countries. On this basis, if a child is born from an Iranian father in America, the child is considered as an American in the eyes of the American government since it considers the place of birth as the criteria for citizenship. However, in the eyes of Iranian government, the child is an Iranian person.

Multiplicity of citizenships after birth

In this context, a person obtains another country's citizenship without losing his/her previous and original citizenship. Like the case of marriage of a French woman to an Iranian man. In this case, the woman will main her previous French citizenship and obtains an Iranian citizenship as well. Based on the article 976 of civil code, the woman is also known as an Iranian.

Practical solution for multiplicity of citizenships

Whenever the issue of personal status of a person with multiple citizenships is 
brought up in a conflict, the judge must only investigate the situation while considering a single citizenship per person. However, the question is that which law should be considered by the judge? If one the citizenships were identical to judge's citizenship then the person is considered with the same citizenship as the judge. The reason for choosing this solution lies in the freedom that has been given to every government regarding selecting its citizens, however, if neither or one of the citizenships were inconsistent with the judge's citizenship, then the effectiveness or superiority of one of citizenships over the other must be investigated. For this investigation, attention must be paid to evidence and situation and also it must be made clear that to which government the person is more attached. International documents have considered several criterions for diagnosis of the effective citizenship. In this regard, paragraph 2 of the article 3 of the statute of international court of justice states: if a person has two citizenships, he/she will be identified as the citizenship of the country who's civil and political rights are similar to the judge's country.

\section{EXCEPTIONS OF ENFORCEMENT OF NATIONAL LAW REGARDING PERSONAL STATUS}

The basis for enforcement of national laws for personal status of foreigners has been stated in article 7 of civil code and is as follows:

1 - Public discipline

2 - Transfer

3 - Genealogy

4 - Qualification (qualification for transformation of citizenship; qualification for exchanging)

5 - Persons with no citizenship

6 - Citizenship differences in personal and domestic relations

\section{Public discipline}

The concept of public discipline has a very high and bold place in private international laws. In fact this concept has been anticipated in laws of most countries and it can be said that it is one of the most important will limitations in private international laws. Formally, public discipline is considered as a preventing lever that prevents and inhibits the enforcement of foreign laws by domestic courts.

In terms of domestic laws, the concept of public discipline is defined as a set of legal organizations and regulations related to morals in interpersonal relations in a way that persons are not able to violate them through private contracts. On the other hand, in terms of private international laws, public discipline is defined as set of organizations that imply that a judge must prefer the domestic laws over foreign or contract laws. On the other hand, in terms of private international laws, public discipline can be considered as an element that by which a judge may refuse to enforce the predetermined foreign rules as a result of having excessive conflicts with domestic laws and rules (SALJUGI, 2017). Public discipline is a mutual exception by which approved foreign laws which are in conflict with those personal status related domestic laws that are already approved by domestic governments, judges are able to prefer the rules of the domestic country over the foreign one. In this regard, article 975 of the civil law states: the court cannot enforce those foreign laws which are in conflict with morals or will result in public anarchy or etc. 


\section{Transfer}

Transfer has been defined as transferring the adequacy or qualification of a law by a foreign country to Iran. By this means, the foreign rule is not enforced and instead, Iranian laws regarding foreign citizens will be enforced. By this means, whenever the government of the citizen considers the personal status of the person as a function of residence law, then Iranian courts must avoid enforcement of the foreign governments' rules and instead, the related domestic rules or laws should be enforced. Whenever the subject of conflict was proving the relatedness of a person whose citizenship also depends on this relation, it is not possible to enforce the origin government's rule regarding personal status. In Iran, first it should be made clear that which government represents the person, and then the laws will be enforced.

\section{Qualification}

Qualification is basically a function of national law. However there are two exceptional cases in which foreigners' national laws are not enforced for determination of their qualification. One is the case of qualification for transformation of citizenship and the other case is qualification for exchanging or trading.

Qualification for transformation of citizenship: citizenship is a major issue in public rights and is an element of dividing people between governments. Therefore, the required qualification for transformation of citizenship must be diagnosed by the governmental law. For this reason, whenever there is a case regarding desertion of an Iranian citizenship or obtaining it, the qualification of the person for both cases should be determined by the Iranian law.

Qualification for exchanging: according to article 7 of Iranian civil code, qualification of foreign citizens in Iran and especially the qualification for exchanging are determined according to the person's government. This principle has been stated in article 962 of the civil code as well, however there are certain exceptions following it. These exceptions are aimed at preserving the rights of citizens of Iran against foreigners who may tend to misuse the lack of awareness of their Iranian counterparts. For example, foreigners who live in Iran may have reached the age of 18 but still being considered as an underage in their own country. Therefore, an Iranian who obtains legal qualification by the age of 18 may be unaware of this situation and may close a deal with the foreigner party. This deal will bring the Iranian party several difficulties, and therefore the article 962 of Iranian civil code states:

Whenever a foreigner carries out a legal operation Iran while being considered as an underage in his/her country; despite the regulations of the foreigner's country, he/she may be considered as qualified for that operation considering Iranian laws. French laws have also considered for this issue and court of France has stated that since French citizens cannot be forced to know the rules of every country, therefore while the French party has made no mistakes, then the contracted cannot be voided based on lack of qualification of the foreigner party based on his/her government's rules.

\section{Persons with no citizenship}

In this regard, the first issue that is faced by a government is to separate the people who it considers as its citizens from other people of the world. Therefore, the most obvious aspect of geographic division of 
people is the subject of citizenship. Citizenship is one of the most important issues in private international laws and is one of the most frequently used words in international laws. Obviously, every person has the right of having a single citizenship and no one can be banned from his/her citizenship or from his/her will to change the citizenship. If we want to describe citizenship we must say that citizenship is defined as a political and spiritual relation that relates a person to a specific government and as a result, both the person and government are provided with determined assignments and rights. Considering this content, it can be concluded that citizenship is a legal relationship since it will benefit from legal effects which have been considered for in rules and laws of a country. On the other hand, it is also a political relation since it results from the power and dominance of the government that considers a person one of its own. Furthermore, the aforementioned relationship is a spiritual relationship since it does not relate to a specific place where the person lives in.

We may face people who have multiple citizenships and we also may face some people who don't have any citizenship at all as a result of losing their citizenship due to wars and etc. These people are known as apartheids. In fact people who have no citizenship are deprived of civil and political rights. In case of apartheid, the sentence regarding personal status is identical to case of those whose countries have no rules regarding personal status. On this basis, in case of the country of Iran, the solution for this issue is enforcement of the court law which is also consistent with components of article 5 of the civil code. However, in countries such as France, the residence law in substituted. On this basis anticipation of some changes in Iran's residence law seems necessary (TAVASOLI 2013).

Citizenship differences in personal and domestic relations

One conflict may be regarding personal statuses of several people with different citizenships. As an example, it can be referred to relations between couples and parents and or children. In these cases several national laws come into conflict and it is harder to sort the situation out (ALMASI, 2011).

\section{CONCLUSIONS}

Considering the fact that personal status is one of the most important issue faced by foreigners, therefore and based on laws, foreigners who live in Iran are judged based on their original government's personal status laws, unless there are certain previously issued treaties between the two governments. With respect to principle 4 of the constitution of Islamic republic of Iran, and also considering for Islamic private international laws regulations, Muslim foreigners who live in Iran will remain under the rule of their original government's rules even in case of existing of a previously issued treaty. As a result of special characteristics of personal status that require persistence and continuity and are related to the whole society, this context has traditionally been a function of either of national law or residence law. Not only the element of will has no defining role in terms of determining the governing law, but also it is considered as the possibility of occurrence of cheating against the law. Therefore, the role assigned to will of people in private international laws is limited. In contrast to laws of 
contracts in which will has an extensive selection range, in terms of the issues related to family rights, the selection of the people or sides of the conflict cannot be anything but the law that has deep bonds with family. In fact, the selected law is identical to the residence or the country of residence. We may face people who have multiple citizenships and we also may face some people who don't have any citizenship at all as a result of losing their citizenship due to wars and etc. These people are known as apartheids. In fact people who have no citizenship are deprived of civil and political rights. In case of apartheid, the sentence regarding personal status is identical to case of those whose countries have no rules regarding personal status.

\section{REFERENCES}

ALMASI, NEJAD ALI. Private international laws, Mizan publishes, 2011, p. 151.

IMAMI, S. HASSAN. Civil rights, volume 4, Ganj Danesh press, 2002, p. 99.

JAFARI, LANGROODI. Law terminology, Ganj Danesh press, 2014, volume 1, p. 717. NASIRI, M. private international laws, Mizan Press, 2016, p. 80.

NOWROOZI, M. rules and regulations governing personal status, Dadgostar press, 2017, p. 2.

SAFAEI, S H. ET AL. persons and the incapacitated. Samt press, 2016, p. 10.

SALJUGI, M. musts of private international law, Mizan Press, 2017, p. 264.

TAVASOLI, NAEINI M. principle of unity of citizenship of couples in law, legal thoughts magazine, 2013, No 7.

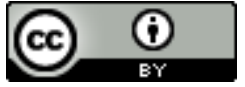

License information: This is an openaccess article distributed under the terms of the Creative Commons Attribution License, which permits unrestricted use, distribution, and reproduction in any medium, provided the original work is properly cited.

Article received on June 09, 2017.

Evaluated July 04, 2017.

Accepted on Jully 04, 2017.

Published on August 18, 2017.

How cite this article (ABNT):

MOHAMMAD, Abasat Pour; RAMAZANI, Behnam; ZADEH, Mahdi Mohammad. Personal status and exceptions of the national law enforcement regarding it. Estação Científica (UNIFAP), Macapá, v. 7, n. 1, p. 61-70, jan./abr. 2017. 